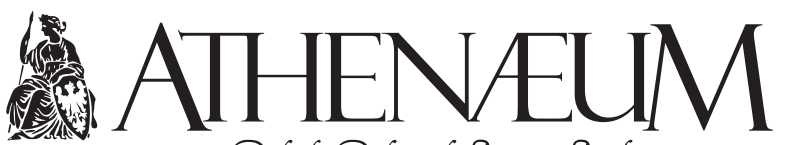

Polish Political Science Studies

Polskie Studia Politologiczne

vol. 63(3)/2019, pp. 137-155

DOI: 10.15804/athena.2019.63.09

www.athenaeum.umk.pl

ISSN 1505-2192

\title{
AUTOCEPHALIZATION OF THE CHURCH IN UKRAINE AS AN ELEMENT OF COMPETITION BETWEEN THE PATRIARCHATES OF CONSTANTINOPLE AND MOSCOW FOR THE LEADERSHIP IN THE ORTHODOX WORLD
}

\author{
AUTOKEFALIZACJA CERKWI NA UKRAINIE \\ JAKO ELEMENT RYWALIZACJI PATRIARCHATÓW \\ KONSTANTYNOPOLITAŃSKIEGO I MOSKIEWSKIEGO \\ O PRZYWÓDZTWO W PRAWOSŁAWNYM ŚWIECIE
}

\section{Stefan Dudra* 우}

\begin{abstract}
- ABSTRACT
After regaining independence, the state authorities of Ukraine undertook actions aimed at obtaining the autocephaly by the local Orthodox Church. This process was difficult due to the existing divisions in Ukrainian Orthodoxy. The most numerous Ukrainian Orthodox Church of the Moscow Patriarchate, with autonomous status, did not show any aspirations for independence from the Russian Orthodox Church. The political activities undertaken in 2018, supported by the Ukrainian Orthodox Church of the Kiev Patriarchate, led to the acquisition of the tomos from the Patriarchate of Constantinople and the creation of the Orthodox Church of Ukraine.
\end{abstract}

Keywords: autocephaly; patriarch; Orthodox Church; Ukrainian Orthodox Church
Po odzyskaniu niepodległości władze państwowe Ukrainy podjęły działania mające na celu uzyskanie przez lokalną Cerkiew prawosławną autokefalii. Proces ten był trudny ze względu na istniejące podziały w ukraińskim prawosławiu. Najliczniejsza Ukraińska Cerkiew Prawosławna Patriarchatu Moskiewskiego, mająca status autonomicznej, nie wykazywała dążeń do niezależności od Rosyjskiej Cerkwi Prawosławnej. Podjęte w 2018 roku działania polityczne wsparte przez Ukraińską Cerkiew Prawosławną Patriarchatu Kijowskiego doprowadziły do uzyskania tomosu od Patriarchatu Konstantynopolitańskiego i utworzenia Prawosławnej Cerkwi Ukrainy.

Słowa kluczowe: autokefalia; patriarcha; Cerkiew prawosławna; Ukraińska Cerkiew Prawosławna

* University of Zielona Góra, Faculty of Humanities. 


\section{INTRODUCTION}

The process of regaining independence by Ukraine affected the divisions in the Orthodox Church. The basis was both historical and political conditions. As a result, the Ukrainian Orthodox Church of the Moscow Patriarchate (hereinafter referred to as the UOC MP), the Ukrainian Autocephalous Orthodox Church (hereinafter UAOC), and the Ukrainian Orthodox Church of the Kyiv Patriarchate (hereinafter the UOC KP) were distinguished ${ }^{1}$. All communities consider themselves as continuators of the tradition of the Kiev metropolis created after the baptism of Kievan Rus in 988. However, they refer to the different historical identity of Ukraine. The above division did not result from doctrinal-theological differences. Despite significant differences in the number of the faithful, all three communities can aspire to the status of a "national state" Church (Wawrzonek, 2014; Krawchuk \& Bremer, 2017).

The administrative structure of the Orthodox Church in Ukraine was formed within the framework of the Kiev Metropolis established between 976 and 998 . Its metropolitans recognized the authority of the patriarch of Constantinople. As a result of the breakup of Kievan Rus and its conquest by Poland, Lithuania and Moscow in the $14^{\text {th }}$ century, the Kiev metropolis broke down into three centers: Kiev, Halych, and Lithuanian. In 1686, the Kiev metropolis, part of the Patriarchate of Constantinople, was subordinated to Moscow (Mironowicz, 2006, pp. 24-26; Bendza, 2006a, pp. 106-107). At the beginning of the $19^{\text {th }}$ century, Kiev lost its metropolitan status and became the eparchy of the Russian Orthodox Church. There was also a process of unification of liturgical differences and rituals according to the Moscow model (Mokry, 1994, p. 85; Ćwikła, 2006, p. 252).

In 1921, as a result of the bottom-up activities of the lower clergy demanding the Ukrainianization of the structures of the Russian Orthodox Church in the Ukrainian territories, the Ukrainian Exarchate was created. Its composition included parishes functioning in the territory of the Ukrainian SSR. In the period of the USSR, after the liquidation of movements for the autocephalization of the Orthodox Church in Ukraine, the Ukrainian Exarchate was the only legal Orthodox religious union in Ukraine. In 1946, after the so-called Council of Lviv, it was also composed of the structures of the Greek Catholic Church (Ramet,

1 UOC MP has about 12,000 parishes and over 9,600 clergy; UOC KP - 4,300 parishes and about 10 million believers, UAOC - 1,200 parishes and 700 clergy. In addition, the Greek Catholic Church can also apply for such status: 3,600 parishes and over 2,400 clergy (Strutyński, 2014, pp. 255-256). 
1984, p. 63; Wilson, 2002, p. 249). This situation has generally survived until the early 1990s.

The aim of the paper is to analyze the growing process of rivalry between Moscow and Constantinople's patriarchates (outlined at the beginning of the $20^{\text {th }}$ century and particularly visible in Western Europe) in the context of changes taking place in Orthodoxy in Ukraine. The fundamental area of the dispute is a different understanding (both in the canonical and historical aspects) of autocephaly (motifs and mode of its transmission). In the past, this concerned, for example, the situation of the Orthodox Church in Poland, which was being reborn after 1918, or the events in Estonian Orthodoxy in the 1990s. The conflict in Orthodoxy in Ukraine (which has a strong political context - Russia's powerful aspirations towards the Ukrainian state) is at the same time an element of a broader competition for leadership in the entire Orthodox world. The main question is whether the Orthodox Church's autocephaly in Ukraine may become a factor that will lead to its unity in Ukraine, or whether it will become an additional element of conflict in the future.

The issue of Orthodoxy in Ukraine, its structural disintegration and the functioning of individual administrative communities is the subject of interest of many researchers. This topic has been the subject of research carried out, among others, by Jurij Czornomoreć, Łesia Kovalenko, Robert Kuśnierz, Tadeusz Andrzej Olszański, Włodzimierz Pawluczuk, Serhii Plokhy and Frank Sysyn, Sabrina Ramet, Maciej Strutyński, Andrzej Szeptycki, Laurent Tatarenko, Myroslav Tataryn, Michał Wawrzonek, and Andrew Wilson. Their inquiries concern theological, historical and political aspects. Against the background of regaining independence by Ukraine and the political transformations taking place there later on, they show the origins of the current problems of the Orthodox Church in this country. They are part of the research related to the new sub-discipline of political sciences - the political science of religion. It is exemplified by, among others, relations between states and religions/Churches, and in a broader perspective of the implemented religious policy. In Ryszard Michalak's view, the state's religious policy consists of "a set of conceptual, programmatic and executive activities undertaken by a homogenous entity of administrative authority or a complex entity of authority (e.g., party and state) in relation to entities representing and creating religious life (religious associations and people)" (Michalak, 2014, p. 5). 


\section{ORTHODOXY IN INDEPENDENT UKRAINE}

In order to understand the situation of Orthodoxy in contemporary Ukraine and to analyze the changes taking place in the context of the research problem, it is necessary to explain the notion of autocephaly and to present the main actors of the Orthodox religious scene.

The Orthodox Church does not have central authority in its organizational structure. Its organization is based on autocephaly, which is one of the basic forms of the system and at the same time constitutes its external foundation. The very concept of autocephaly is defined as the independence of the national (local) church and independence from the superior spiritual authorities abroad, while maintaining the unity of faith (religion, confession), sacraments and canonical principles (Znosko, 1971, pp. 42-44; Sokołowski, 2013). A characteristic feature of every Orthodox Church is independent solving all intra-church problems and the right to set up bishops, including its superior (Łotocki, 1932, pp. 16-17; Bogolepow, 1961, p. 11; Kałużny, 2008, p. 60). The autocephalous church does not break dogmatic and canonical unions with other Orthodox Churches, which together form the Universal Orthodox Church, and recognize the priority of the honorary Patriarch of Constantinople ${ }^{2}$.

The local Churches are independent, but this independence cannot exceed certain specific boundaries. None of them can introduce new dogmas and violate the legal principles of the Universal Church. Unjustified rejection of ancient church traditions and customs is prohibited. In addition, each national Church should respect the local privileges of other Churches (Znosko, 1973, pp. 172-173). The essence of autocephaly is in the fact that the autocephalous Church is an independent source of power and has equal rights with other Churches ${ }^{3}$.

2 According to Fr. Aleksei Znosko, autocephaly is "the independence of the national (local) church as a separate unit recognized in the Universal Church, combined with the other Churches with unity of faith and canonical principles" (Znosko, 1973, p. 172; Papierzyńska-Turek, 1989, p. 15). On the canonical factors, the importance and conditions of obtaining autocephaly, see: Zyzykin, 1931; Sokołowski, 2013; Mossakowski, 2012.

3 Currently, 14 Orthodox Churches according to the diptych of the Patriarchate of Constantinople are considered autocephalous ( 4 ancient Eastern patriarchies: Constantinople, Alexandria, Antioch, and Jerusalem, 5 patriarchs established later: Russia, Serbia, Romania, Bulgaria, Georgia; 5 autocephalous churches not having the rank of patriarchy: Cyprus, Greece, Albania, Poland, and the Czech Republic and Slovakia). In diptychs of the Moscow Patriarchate, the Orthodox Church in America is additionally mentioned (its status of autocephaly obtained for the Moscow Patriarchate is not recognized by some Orthodox churches). The priority of the Patriarchate of Constantinople is seen as 
A necessary condition for the separation of the Church's component and the receipt of autocephaly is the possession of, among others, the required number of bishops: minimum 4 active hierarchs ${ }^{4}$. This isolation depends on the special circumstances created (e.g., changes in the state division of the territory). In addition, obtaining the consent of all autocephalous Churches, including the mother church. The proclamation of autocephaly in order to satisfy national aspirations is rejected. The principle of the unity of the Universal Church requires that the newly-created autocephalous Church establishes communication and a canonical community with all autocephalous Churches. There are no separate canons for its establishment. The procedures were based on canon law and legal awareness of individual Churches. In practice, three basic elements were considered: motivations for the establishment of autocephaly, canonical conditions necessary for its functioning, and legal factors creating autocephaly (Znosko, 1973, p. 174; Kałużny, 2008, p. 361). An important motive in the pursuit of the Church for autocephaly was independence for a given country (including the case of Poland after 1918). In the past, the Orthodox churches obtained the status of autocephaly after the influence of various factors, often due to political conditions and changes in the political system (e.g., the Patriarchate of Constantinople did not recognize the autocephaly of the Polish Autocephalous Orthodox Church from 1948, it accepted the state of affairs only in 1959) ${ }^{5}$. Currently, there are two methods of establishing autocephaly: granting by the mother church or the Patriarchate of Constantinople, which in this respect recognizes its special competence. The indefiniteness of its establishment gives rise to conflicts in Orthodoxy. Nevertheless, in both cases it is necessary to confirm such a decision by the other autocephalous Churches (Zyzykin, 1931, pp. 36-37; Przekop, 1978, pp. 207-208).

the honorary primacy of primus inter pares (Kałużny, 2008, pp. 60-61). The characteristics of autocephalous churches are presented in: Mińko, 2009, pp. 201-218.

4 Autocephaly is built and conferred on the principle of territorial unity (a departure from the principle of territorial unity is diaspora). In addition, the condition for the local Church to apply for autocephaly status is: church organization, centers of monastic life (male and female monasteries), having a seminary or academy for future priests (about the conditions for giving the local autocephaly to the local churches, see: Tofiluk, 2006, pp. 18-20).

5 Among other things, the Bulgarian Church in 1872, violating the canons, declared itself autocephalous (it was recognized only in 1945); the Moscow Patriarchy did not recognize the autocephaly of the Orthodox Church in Poland in 1925 (see more: Langrod, 1931, p. 62 et seq.; Roberson, 1995, pp. 55-101; Bendza, 2006; Dudra, 2014, pp. 59-70; Borkowski, 2015). 
The controversy over the method of obtaining and conferring autocephaly was reflected in the preparatory work for the All-Orthodox Council ${ }^{6}$. The preliminary text on the "Autocephaly and the way it was announced" was adopted by the Inter-Orthodox Preparatory Commission at its 1993 session in Chambésy. It was proposed that all autocephalous Orthodox churches represented by their superiors should give it and that they would announce it jointly and solemnly. Discussions are underway regarding the issue of signatures by supervisors under the tomos autocephaly (e.g., the discrepancies concern whether only the signature of the Ecumenical Patriarch is sufficient). Ultimately, in the absence of an agreement and the adoption of a common position, it was decided that the topic: "Autocephaly in the Orthodox Church and the procedure for its announcement" was to be considered further in the preparatory committee and was not finally referred to the debate of the General Orthodox Council'.

At the dawn of independence at the All-Ukrainian Religious Forum, state authorities with the voice of Leonid Kravchuk (chairman of the Verkhovna Rada of Ukraine) stated that "All religions, churches and religious associations are equal. Therefore, no state, no privileged, no prevailing religion, no Church [is in Ukraine] - ours or not. All religions that the citizens of Ukraine profess are ours because our people believe in them [...]. The appeals for the creation of one national Church [...] were born of the romanticism of national revival" (quoted after Wilson, 2002, p. 248).

6 Already in 1956, the Greek Church proposed the inclusion of this issue in the list of topics of the future Council. In 1961, after the arrangements in Rhodes, the issue was clarified and it was specified that it was mainly about the "announcement of autocephaly": who announces the conditions and restrictions and the manner in which it is announced. In 1976, the whole issue was entitled "Autocephaly and the way it is announced" (these issues are discussed in greater detail by Kałużny, 2008, pp. 367-372). At the global level, the universal (ecumenical) council is the highest expression of the Church's conciliar structure. The goal of the meeting of bishops is to solve problems of universal importance. It is worth emphasizing that the first ecumenical council was the Council of Nice (325), and the last was the Second Council of Nice of 787. Since then, despite the attempts made, the Orthodox council has not been convened. Today, the genesis of the Council's convocation should be seen in the activities of Ecumenical Patriarch Joachim III at the beginning of the $20^{\text {th }}$ century. Despite several conferences (including Constantinople - 1923, Mount Athos - 1930, Athens - 1936, Moscow - 1948), the acceleration of works did not take place until the 1960s. After the preparation of the most important topics, the date of convening the Council was set for 2016 (see more: Paprocki, 1999, pp. 203-208; Kuźma, 2016, pp. 151-168).

7 For more on the discussion and discrepancies about autocephaly between the Churches, see: “Wiadomości PAKP”, 2014, pp. 7-9; “Wiadomości PAKP”, 2016, p. 5. 
In January 1990, according to the decision of the Synod of Bishops of the Russian Orthodox Church, the Ukrainian Exarchate was liquidated. Despite the announcement of Patriarch Alexey II about giving the Orthodox Church in Ukraine autocephaly, only the autonomous Ukrainian Orthodox Church of the Moscow Patriarchate was established (Plokhy \& Sysyn, 2003, pp. 91-92). The Moscow Patriarchy feared the autocephalization of the Orthodox Church and the loss of a significant part of the church structures and the faithful. Proponents of independence were accused of "politicizing religion" and the pursuit of schism In spite of this, some of the hierarchs of the UOC MP, with metropolitan Philaret (Denysenko) at the head, began to emphasize that it is not a Russian-oriented church. The exemplification of this was, among others, participation in Ukrainian patriotic celebrations, and in the seminary in Odessa Ukrainian language was introduced as a language of instruction (Pawluczuk, 1998, p. 130). Supporters of autocephaly, mostly with support in the western dioceses of Ukraine, also received support from some Ukrainian Orthodox intelligentsia (Ramet, 1984, pp. 64-65; Plokhy \& Sysyn, 2003, pp. 95-96).

After the declaration of independence by Ukraine, metropolitan Philaret convened in November 1991 the Council of Bishops of the Ukrainian Orthodox Church, which issued an official request to the Moscow Patriarchate for autocephaly (this decision was not supported by four hierarchs). However, the Russian Orthodox Church did not agree. Probably this was due to the fear of losing the important, both in terms of material and the number of the faithful, the Orthodox center. At the same time, contacts were established with the Patriarchate of Constantinople (Plokhy \& Sysyn, 2003, pp. 117-121).

The autocephaly case was discussed at the Council of Bishops of the Russian Orthodox Church (April 1-3, 1992). Despite the assurances of metropolitan Philaret, the Orthodox Church in Ukraine meets all the conditions of autocephalization, moreover, as a body independent of Moscow could compete more effectively with the Greek Catholic Church and UAOC; the Council gave support to the opponents of autocephaly (metropolitan Philaret was also requested to resign). In the absence of the subordination of metropolitan Philaret to the deci-

8 At the beginning of 1991, the Ukrainian Orthodox Church of the Moscow Patriarchate had officially 5031 pastoral institutions (as late as 1988-1991, the communist authorities handed over the previously closed churches to the Moscow Patriarchate, so that they would not be taken over by Greek Catholics or supporters of autocephaly). According to data from January 1, 1992, the jurisdiction of the Moscow Patriarchate was recognized in Ukraine by 5473 parishes (see: Plokhy \& Sysyn, 2003, pp. 104-105). 
sions of the Council of Bishops of the Russian Orthodox Church, the Ukrainian hierarchs were released from obedience to the metropolitan (Plokhy \& Sysyn, 2003, p. 123; Pawluczuk, 1998, pp. 131-132).

Following the aforementioned decisions, on May 27, 1992 in Kharkov, Nicodemus (Rusnak) (without metropolitan Philaret) led a synod of bishops UOC MP, who announced that he would deprive Philaret of the office and elect a metropolitan Volodymir (Sabodan). Despite the negative position of the Ukrainian authorities, which recognized the synod as illegal, the dismissed metropolitan practically lost the support of the entire clergy of the Church'.

Metropolitan Philaret considered this decision void. At the same time, he began talks about unification with $\mathrm{UAOC}^{10}$. They ended with success and the UOC KP was established at the All-Ukrainian Orthodox Council (June 25-26, 1992) ${ }^{11}$. From the beginning of its existence, the church tried to play the role of the "patriotic and state" Church. Its separation was favorably received by the then

9 Therefore, he asked the UAOC to join his episcopate, breaking the link with the Moscow Patriarchate. The metropolitan Philaret, on May 27, 1992, was removed from Kiev Cathedral by a decision of the Council of Bishops of the Ukrainian Orthodox Church and suspended in the performance of his duties; on June 11, 1992, the Council of Bishops of the Russian Orthodox Church confirmed this decision and excluded him from the clergy, depriving him of all priestly degrees; in 1997, he was excommunicated. These decisions were recognized by all local Orthodox churches, including the Patriarchate of Constantinople (see: Plokhy \& Sysyn, 2003, pp. 118-133; Czykwin, 2018d, p. 18).

10 UAOC is a community based on the faithful from the Ukrainian Diaspora in the United States, Western Europe and the western part of modern Ukraine. It refers to the autocephaly which was announced in January 1919 by the Directorate of the Ukrainian People's Republic. In 1921, the All-Ukrainian Orthodox Council also proclaimed autocephaly, which was initially recognized by the Council of the Russian Orthodox Church under the influence of the Soviet authorities. However, in 1930 it was decided to dissolve the Ukrainian Autocephalous Orthodox Church, and in 1934, the Russian Orthodox Church revoked the autocephaly previously granted. During the German occupation, the structures of the Ukrainian Autocephalous Orthodox Church were renewed, and after the defeat of Germany, most of the hierarchy emigrated, mainly to Canada and the USA. Events connected with the baptismal millennium of St. Vladimir in Ukraine influenced the formation of the committee for the rebirth of Ukrainian autocephaly. Since 1988, there has also been a movement for autocephalization. Finally, in August 1989, the restitution of the Ukrainian Autocephalous Orthodox Church was announced in St. Peter and Paul's Church in Lviv. Despite the crisis (e.g., in 1992 some of the faithful joined the UOC KP), its administrative structures were renewed. It took on a national and independence face. Since 2015, the head of the Church is the metropolitan Makary (Maletych) (see: Ramet, 1984, pp. 63-65; Plokhy \& Sysyn, 2003, pp. 89-90; Kuśnierz, 2006, pp. 107-113; Borkowicz, 2014).

11 The current head of UAOC, Mstyslav (Skrypnyk), was elected the Kiev and All-Ukrainian Patriarch. After his death in 1993, the group of his supporters made secession and the revival of the Ukrainian Autocephalous Orthodox Church came into being. 
Ukrainian authorities (Strutyński, 2014, p. 260; Wilson, 2002, p. 249). In view of the negative position of the Moscow Patriarchate, the Ukrainian authorities ceased their efforts to build an autocephalous Ukrainian church in accordance with canon law and supported the former metropolitan Philaret in these activities (Plokhy \& Sysyn, 2003, p. 140).

The internal Orthodox split (roskol) led in the first half of the $1990^{\text {s }}$ to the emergence of unapproved by the world Orthodox structures: UOC KP and UAOC. Both competed with the Ukrainian Orthodox Church with the jurisdiction of the Moscow Patriarchate ${ }^{12}$. The problem is also the Greek Catholic Church. As a result of its creation in 1596, "a civilizational split occurred in Ukraine. The ethnically and ethnoculturally homogeneous nation was divided and found itself in two differently civilizational systems - the greater part of Ukraine remained in the Orthodox-Byzantine, the smaller part - later Galicia - in the western - Catholic one. This event has left a deep mark on the entire subsequent history of the Ukrainian nation"13. In addition, it also complicated the religious situation in Ukraine.

\section{THE WAY TO AUTOCEPHALY}

Since the 1990s, the existing Orthodox churches have been treated instrumentally by Ukrainian politicians. They were used for specific political purposes and were involved in the current party struggle (often the issue of unification of all Orthodox communities and the issue of autocephaly was an argument) (Tataryn, 2001, pp. 161-165; Strutyński, 2014, pp. 260-261; Tatarenko, 2017, pp. 25-30). In fact, this was contrary to the law in force. The basic act guaranteeing freedom of conscience and religion in Ukraine is the Constitution (passed on June 28, 1996). Article 35 states that "Everyone has the right to choose his or her worldview and religion freely. This right includes the freedom to profess any religion or not to profess any religion, to participate without hindrance individually or in groups

12 It has full financial and administrative autonomy and independence (including the election of bishops) from the Moscow Patriarchate. Since the 1990s, the number of UOC MP parishes has been steadily growing (in 1993, there were 5449 pastoral institutions in its structure, in 1997-6882, and in 1999-8168). At the same time, the Ukrainian state authorities handed over sacral facilities to non-canonical Orthodox churches and supported their activities (Wilson, 2002, pp. 250-251).

13 More on the historical conditions of the activities and development of the Greek Catholic Church in Ukraine, see: Wilson, 2002, pp. 261-263. 
in religious practices and rites, to conduct religious activities [...]. The Church and religious organizations in Ukraine are separated from the state, and the school from the Church. No religion can be recognized by the state as ruling"14. Actions taken at a later stage by the state authorities interfering in the religious life of Orthodox churches (including support for non-canonical churches) were contrary to constitutional provisions.

Today, the Orthodox religious conflict in Ukraine is intensified by the conflict with Russia, the socio-political and economic crisis (Olszański, 2014; Tatarenko, 2017). It is worth emphasizing that Ukraine in the plans of the Moscow Patriarchate is included, together with Russia and Belarus, in the concept of the "Russian world". Its propagator is Patriarch Cyril, who expresses his belief in the religious unity of Russia, Ukraine and Belarus (Szeptycki, 2011, pp. 64-75; Wawrzonek, 2016, pp. 37-70). A propaganda campaign launched in 2009 for the idea of the "Russian world" as an integral "geopolitical space, whose specific character is constituted by three elements: the Russian type of Orthodoxy, traditions of Russian statehood and social life, and the Russian language" (Czornomoreć, 2014). For most Orthodox Churches in Ukraine, this concept is identified with the imperial aspirations of the Russian Orthodox Church (Strutyński, 2014, p. 267).

The aim of the Ukrainian authorities is to create one Orthodox Church, independent from Moscow. UOC KP and UAOC have become an ally in these activities. In fact, after Ukraine's independence, the Orthodox Church there meets all but one of the conditions necessary to be an autocephalous Orthodox Church. This condition is the acceptance by most clergy and faithful hierarchies of the change in the current status (Czykwin, 2018a, p. 40). Nevertheless, the existing religious divisions resulted from the political actions of the Ukrainian authorities and, to some extent, from the personal ambitions of the Orthodox hierarchy. It should be understood that an independent Ukraine needed a church whose center of power would be within its borders. It would foster the development of state and national self-awareness. It would become an important element of national revival and be the basis for building Ukrainian statehood.

On February 24, 2014, the UOC MP took steps towards the creation of a single Orthodox Church jurisdiction. A special commission for talks with

14 Freedom of conscience and religion was also guaranteed in the Act on Freedom of Conscience and Religious Organizations of 23 April 1991, more broadly on religious regulations, main principles of state and church relations and the status of religious organizations (see: Strutyński, 2014, pp. 257-258; Kovalenko, 2002, pp. 79-109). 
the UOC KP was established. Initial consent of the parties was obtained that unification will take place on the basis of canonical law. During the talks, the main problem was the question of the authority of the united Orthodox Church (the head of the UOC KP patriarch Philaret saw only his own person in the role of the superior) $)^{15}$. On June 24, 2015, the Synod of UOC MP also decided to continue the dialogue with UAOC. However, these initiatives did not bring positive results. Generally, the problem is the unification model. UOC MP expects the "return of the disconnected", while UOC KP and UAOC prefer the model of unification of "all with each other" (Olszański, 2014, p. 6). The question of overcoming Orthodox divisions in Ukraine and giving them the status of a single and indivisible autocephalous Orthodox Church is one of the key problems for modern Orthodoxy. It was also a topic of discussion during the session of the All-Orthodox Council, which met in Crete in June 2016 (however, this topic was considered outside the agenda) (Przeciszewski, 2018).

By 2018, UOC MP was the only Orthodox administration in the territory of Ukraine whose canonicity was recognized by other local Orthodox Churches. The main problem was its perception of a part of the political scene as a political instrument of Russia, "the view is imposed that it is a foreign, even hostile element in the life of the nation". It is accused by Ukrainian nationalist organizations of "lack of patriotism" and "the use of an aggressor" (Czykwin, 2017, pp. 27-29). It became an element of the political game. As a result, a group of deputies from the Petro Poroshenko Bloc and the People's Front filed two bills (No. 4128 and $\left.4511^{16}\right)$ in the Verkhovna Rada of Ukraine, the adoption of which would give the anti-Orthodox radicals unlimited possibilities of interference in the internal affairs of UOC MP, including its legal liquidation ${ }^{17}$.

15 On the part of the UOC MP on unification, three principles were proposed: the superior from the UOC MP, the Holy Synod will act on the parity basis, minority rights will be guaranteed by making decisions by the majority vote (see: Czornomoreć, 2014).

16 Project 4128 provided for the procedure of taking over the temples by changing the "self-identification of the religious community", Project No. 4511 "on the special statute of religious organizations whose head offices are in the countries recognized by the Verkhovna Rada of Ukraine as the aggressor state" (see: Tatarenko, 2017, p. 27).

17 Both UPC and the Churches and religious associations associated in the All-Ukrainian Council protested against the adoption of laws that violated the Ukrainian constitution guaranteeing religious freedom (apart from UOC KP), the Roman Catholic bishops and the Holy See, the World Council of Churches and the heads of the autocephalous Orthodox Church also took a firm stance (see: Czykwin, 2017, p. 29). 
The above actions also met with the international reaction. The Secretary General of the World Council of Churches pastor Olav Fykse Tveit in the letter addressed to the Ukrainian authorities expressed "deep concern" with the perspective of accepting "actions that are in conflict with the activities undertaken in Ukraine, supporting the development of democracy [...]. The World Council of Churches believes that the adoption of these laws will be a threat to the principle of religious freedom, the principle of equality before the law of churches and religious associations existing in Ukraine, and may provoke a new wave of tension in Ukrainian society" (quoted in Czykwin, 2017, p. 31). In view of the protests, the projects were withdrawn on May 18, 2017.

The Ukrainian authorities took up the matter of autocephaly. The whole process was additionally strengthened by earlier events: the Orange Revolution in 2004, Euromaidan in 2013, and finally the annexation of Crimea by Russia and Russian aggression towards eastern Ukraine (Szostkiewicz, 2018). On April 17, 2018, President Petro Poroshenko, at an extraordinary meeting with the leaders of the political parties represented in the parliament, announced that he had handed Patriarch of Constantinople Bartholomew I to the request concerning the autocephaly of the Ukrainian Orthodox Church. On April 19, the Verkhovna Rada of Ukraine made a similar declaration ${ }^{18}$.

On 21 April 2018, the official statement of UOC MP appeared, in which it was clearly stated that it remained "in communion with world Orthodoxy, did not ask Patriarch Bartholomew I to give autocephaly to the Orthodox Church of Ukraine and did not grant any powers in this matter nor the president or the Verkhovna Rada"19. In addition, a statement adopted on June 15, 2018 by the bishops stated that: "The current canonical status completely provides opportunities for the Ukrainian Orthodox Church to successfully carry out its mission among the Ukrainian people. Attempts to change this status will limit the rights and freedoms of our Church. Attempts to change the current status will not heal, and will deepen the wounds of the current race in both Ukrainian Orthodoxy and in Ukrainian society" (quoted in Czykwin, 2018b, p. 41). De facto,

18 The request was also supported by representatives of the non-canonical UAOC (Czykwin, 2018a, p. 40; Przeciszewski, 2018; Romanowski, 2018).

19 On May 9, 2018, in the face of the events in Ukraine, the Council of Bishops of the Polish Autocephalous Orthodox Church also expressed its opinion. In its adopted position, it stressed that "the Orthodox Church's church-canonical life should be based on the principles based on the dogmatic-canonical science of the Orthodox Church. Violation of this principle brings chaos to the life of the Orthodox Church" (see: "Wiadomości PAKP", 2018, p. 9). 
UOC MP found itself in a difficult position. It retains a canonical bond with the Moscow Patriarchate, while the Russian Federation in Ukraine was proclaimed an aggressor.

At the beginning of September 2018, the envoys of the Constantinople's Patriarch of Ukraine were sent to Ukraine: Archbishop of Panphilia Daniel from the Ukrainian Orthodox Church in the USA and Bishop Hilarion from the Ukrainian Greek Orthodox Church of Canada. The Hierarchs as exarchs of Patriarch Bartholomew I during their visit to President Petro Poroshenko declared that they had come "with an extraordinary mission to continue the work on the decision already taken to start the autocephaly process of the Ukrainian Orthodox Church" (Czykwin, 2018c, p. 21; Sterlingow, 2018). These actions were critically received by the Russian Orthodox Church. Constantinople was accused of violating canon law.

On October 11, 2018, the Ecumenical Patriarchate began the process of "proceeding" to obtain autocephaly for the Church in Ukraine. However, it was not determined which jurisdictional structure of the Ukrainian Orthodox Church is to achieve autocephaly: UOC MP, UOC KP, or UAOC. Representatives of the Ecumenical Patriarchate informed about the annulment of the provisions of the Moscow Patriarchate from 1686. Thus, Ukraine again became the canonical territory of Constantinople. At the same time, the Patriarchate of Constantinople proclaimed the removal of anathema from the head of Kiev's Patriarchate Philaret. This was tantamount to recognizing the entire structure as legally operating in the light of church canons (Vassiliadis, 2018; Kobeszko, 2018). The metropolitan Makary (Maletych) was also considered a canonical bishop of the Orthodox Church. Thus, the entire UAOC was legalized ${ }^{20}$. The next

20 The bishops of the Russian Orthodox Church expressed their position on the situation. On October 15, 2018, after the Synod meeting in Minsk, the hierarchy assessed the recent decisions of Constantinople as "non-canonical", adopted "unilaterally, ignoring the appeals of the Ukrainian Orthodox Church and the whole Russian Orthodox Church, as well as the sister local Orthodox Church, their superiors and archbishops for a pan-Orthodox discussion of the problem". It was decided to break the Eucharistic unity with the Ecumenical Patriarchate (it broke relations and forbade his faithful and clerical liturgical contacts with the clergy subordinate to the Constantinople patriarchy). The other 13 Autocephalous Churches were also appealed to take the same steps. The hierarchy of other Orthodox Churches also expressed their position. Serbian Patriarch Hieronymus said: "Our first hierarchy, the ecumenical patriarch, has succumbed to the temptation to make decisions that may prove disastrous for the Orthodox Church - the temptation to do what he has no right to do - to recognize the structures of the raskol as an Orthodox church, and even to give them autocephaly". The Council of Bishops of the Polish Autocephalous Orthodox Church in the face of the events in Ukraine maintained the position expressed in the resolution of May 9, 2018. It called for a meeting 
scenario was to call a council where the UOC KP and UAOC would be merged and its superior would be elected. The finale was to be handed over by patriarch Bartholomew I the tomos on autocephaly. The auto-deployment process initiated by the Ukrainian state authorities received additional international support. The US has been involved in this issue. The Secretary of State Mike Pompeo on the official website of the department posted an entry addressed to Ukrainians: "We urge the Church and state authorities to continue the process of creating the Ukrainian autocephalous Church. The US reiterates its declaration on the promotion of religious freedom and the freedom of religious communities, including the Orthodox ones in Ukraine" (quoted in Czykwin, 2018d, p. 20).

Eventually, the unification council of Orthodox Churches in Ukraine took place on December 15, 2018. Bishop Epiphanius (from the UOC KP) was elected the head of the autocephalous Orthodox Church of Ukraine ${ }^{21}$. Tadeusz A. Olszański rightly observes that "The conduct of the Council and the election of the head of the unified Church are not tantamount to the end of the split in the Ukrainian Orthodox Church. This is only the beginning of a complicated process, which may cause a number of conflicts within Ukraine and in Ukrainian-Russian relations [...]. In Ukraine there will be two equal and similarly strong structures (in terms of the number of dioceses, although in terms of the number of parishes the UPC prevails), with a hostile attitude towards each other. The PCU and the UPC will enjoy strong support from Russia and Ukraine, respectively, which only makes their instrumentalization for political purposes possible" (Olszański, 2018).

The Council's succession was the tomos of the Patriarchate of Constantinople on January 6, 2019, to the Metropolitan of Kiev, Epiphanius: "We unanimously define and announce that the entire Orthodox Church within the boundaries

of all superiors of the Orthodox Churches. At the same time, it forbade PAOC priests to enter into liturgical and praying contacts with "clergy" of the so-called "Kiev Patriarchate" and the so-called "Autocephalous Orthodox Church". Metropolitan Rostislav, the head of the Orthodox Church of the Czech Lands and Slovakia, also supported the UOC MP (see: „Przegląd Prawosławny”, 2018a, pp. 17-20; Kobeszko, 2018a).

21 The Council was attended by only 2 hierarchs from UOC MP: Metropolitans Symeon (Shostatsky) and Aleksander (Drabinko). For their participation in the Council, they were released from the leadership of the eparchies and suspended from their duties. On the day of the Council, President Poroshenko stated that this was the day of Ukraine's final independence from Russia. It is gaining spiritual independence, which can be compared to gaining political independence. It cuts off the ties that linked Ukraine with the Russian Empire. The autocephaly of the Ukrainian Orthodox Church itself is a question of Ukraine's national security (see: Czykwin, 2019, pp. 12-13; Olszański, 2018). 
of a politically formed and completely independent Ukrainian state [...] is now a canonical autocephaly, independent and self-governing" (Łomanowski, 2019). It can be assumed that the autocephaly model (being the theological aspect) is included and used for political reasons in a concept aimed at promoting local churches that are to be a factor in the consolidation of emerging or regenerating countries, e.g., the case of Poland already referred to after 1918 (Dudra, 2014). The finalization of the auto-deployment process is the political and diplomatic success of President Petro Poroshenko (however, it did not strengthen, as it was assumed, its position in the presidential elections, which were a failure). He believed that independent Ukraine needs a sovereign Church. He rightly stated that Russia through UOC MP is rebuilding its influence (political and ideological) in Ukraine. Receiving the tomos in 2019 is strengthening the foundation of independent Ukraine.

\section{CONCLUSIONS}

The cooperation of the Ukrainian authorities with the Patriarchate of Constantinople, giving autocephaly, will not lead to the unity of Orthodoxy in Ukraine. It will create new divisions in the state and in the Orthodox world. It will contribute to the revival of the missionary activity of other Churches (including Roman Catholic, Protestant and Greek Catholic structures). At the same time, the unification of the three Ukrainian Orthodox Churches would give one of the largest Orthodox Churches in the world and an opportunity to build a national identity that would undoubtedly contribute to the strengthening of Ukrainian statehood. Moreover, it would significantly weaken both materially and prestigiously the Moscow Patriarchate: UOC MP today has 12,348 parishes - only 4694 fewer than the Patriarchs of Moscow have in all of Russia (Radziwinowicz, 2018).

As a result of autocephaly in Ukraine, there may be a split in the Orthodox world and a possible uprising, as highlighted by metropolitan Hilarion describing "two families of Orthodox churches" (recognizing the primacy of Constantinople and supporting the position of the Moscow Patriarchate) ${ }^{22}$. At the same time, the religious conflict in Ukraine is part of a wider jurisdictional dispute between the

22 For more on the consequences of autocephaly in Ukraine, see: Mamy nadzieje, że Moskwa sie opamięta. Z arcybiskupem Telmissos Hiobem (Gecza) z jurysdykcji patriarchatu konstantynopolitańskiego rozmawiają dziennikarze BBC („Przegląd Prawosławny”, 2018b, p. 20). 
Patriarchates of Constantinople and Moscow for the presidency of the Orthodox world. Its exemplification is, among others, the church situation in Estonia (Dudra, Król-Mazur, \& Maj, 2018, pp. 117-122). They are factors that divide and weaken contemporary Orthodoxy. It seems that in the future the creation of one church structure in Ukraine will be extremely difficult. This is due to: political factors (Ukrainian-Russian relations, the problem of "self-proclaimed republics" of the Donetsk People's Republic and Luhansk People's Republic) and organizational ones (perception of creating one local church only by absorbing one structure by another and the importance of individual structures) (Tatarenko, 2017, pp. 28-29).

\section{REFERENCES:}

Bendza, M. (2006). Droga Kościoła prawosławnego w Polsce do autokefalii. Białystok: Wydawnictwo Uniwersytetu w Białymstoku.

Bendza, M. (2006a). Inkorporacja metropolii kijowskiej do patriarchatu moskiewskiego. In: A. Mironowicz, U. Pawluczuk, \& P. Chomik (eds.). Autokefalie Kościoła prawosławnego w Polsce (pp. 65-114). Białystok: Wydawnictwo Uniwersytetu w Białymstoku.

Bogolepow, A. (1961). Conditions of Autocephaly. St. Vladimir's Seminary Quarterly, 5(3), 11-37.

Borkowicz, J. (2014). Cyryl traci Cerkiew na Ukrainie. Więź, 3. Retrieved from: https:// www.wiez.pl/czasopismo/;s,czasopismo_szczegoly,id,580,art,16091.

Borkowski, A. (2015). Między Konstantynopolem a Moskwą. Źródła greckie do autokefalii Kościoła prawosławnego w Rzeczypospolitej (1919-1927). Białystok: Wydawnictwo Uniwersytetu w Białymstoku.

Krawchuk, A., \& Bremer, T. (eds.) (2017). Churches in the Ukrainian Crisis. London: Palgrave Macmillan.

Czornomoreć, J. (2014). Ukraińskie prawosławie wobec cerkiewnego putinizmu. Więź, 3. Retrieved from: https://www.wiez.pl/czasopismo/;s,czasopismo_szczegoly, id,580,art, 16092 .

Czykwin, E. (2017). Nieważne są ściany, lecz ludzie. Przegląd Prawosławny, 7, 28-29.

Czykwin, E. (2018a). Rozłam coraz głębszy. Przeglą Prawosławny, 6, 39-41.

Czykwin, E. (2018b). W okowach polityki. Przeglad Prawosławny, 9, 40-41.

Czykwin, E. (2018c). Kryzys się pogłębia. Przegląd Prawosławny, 10, 20-22.

Czykwin, E. (2018d). Rozdzieranie ukraińskiej Cerkwi. Przegląd Prawosławny, 11, 17-20.

Czykwin, E. (2019). Rozłam się pogłębił. Przegląd Prawosławny, 1, 12-13.

Ćwikła, L. (2006). Polityka władz państwowych wobec Kościoła prawosławnego i ludności prawosławnej w Królestwie Polskim, Wielkim Księstwie Litewskim oraz Rzeczypo- 
spolitej Obojga Narodów w latach 1344-1795. Lublin: Wydawnictwo Katolickiego Uniwersytetu Lubelskiego.

Dudra, S. (2014). Autokefalie Polskiego Autokefalicznego Kościoła Prawosławnego w polityce władz polskich i Patriarchatu Moskiewskiego. In: R. Michalak (ed.). Religijne determinanty polityki (pp. 59-70). Sieniawa Żarska: Wydawnictwo Morpho. Dudra, S., Król-Mazur, R., \& Maj, D. (2018). Polityka wyznaniowa. Wschodnia i ekumeniczna perspektywa eklezjalna. Zielona Góra: Pracownia Badań nad Mniejszościami Narodowymi i Etnicznymi Uniwersytetu Zielonogórskiego.

Kałużny, T. (2008). Nowy sobór ogólnoprawosławny. Natura, historia przygotowań, tematyka. Kraków: Dehon.

Kobeszko, Ł. (2018). O co chodzi w kwestii autokefalii na Ukrainie? Aleteia. Retrieved from: https://pl.aleteia.org/2018/10/16/o-co-chodzi-w-kwestii-autokefalii-naukrainie/.

Kobeszko, Ł. (2018a). Patriarchat Ekumeniczny rehabilituje Patriarchat Kijowski $i$ Cerkiew autokefaliczną. Retrieved from: https://www.ekumenizm.pl/koscioly/ wschodnie/patriarchat-ekumeniczny-rehabilituje-patriarchat-kijowski/.

Kovalenko, Ł. (2002). Podstawowe regulacje wyznaniowe w prawie ukraińskim. Studia $z$ Prawa Wyznaniowego, 5, 79-109.

Kuśnierz, R. (2006). Próba kościelnej niezależności. Ukraińska Autokefaliczna Cerkiew Prawosławna (1919-1936). Więź, 6, 107-113.

Kuźma, A. (2016). Udział Polskiego Autokefalicznego Kościoła Prawosławnego w przygotowaniach Soboru Wszechprawosławnego. In: T. Kałużny, \& Z. Kijas (eds.). Przed Soborem Wszechprawosławnym (pp. 151-168). Kraków: Wydawnictwo Naukowe.

Langrod, J.S. (1931). O autokefalii prawosławnej w Polsce. Studjum z zakresu polskiej polityki i administracji wyznaniowej. Warszawa: Instytut Wydawniczy „Biblioteka Polska".

Łomanowski, A. (2019). Autokefalia na Ukrainie. Wojna o wiarę prawdziwą. Retrieved from: https://www.rp.pl/Kosciol/301069966-Autokefalia-na-Ukrainie-Wojna-owiare-prawdziwa.html.

Łotocki, A. (1932). Autokefalia. Zasady autokefalii. Warszawa: Instytut Wydawniczy „Biblioteka Polska”.

Michalak, R. (2014). Polityka wyznaniowa państwa polskiego wobec mniejszości religijnych w latach 1945-1989. Zielona Góra: Oficyna Wydawnicza Uniwersytetu Zielonogórskiego.

Mińko, A. (2009). Kościół Prawosławny. In: H. Tranda, \& M. Patalon (eds.). W drodze za Chrystusem. Kościoły chrześcijańskie w Polsce mówia o sobie (pp. 197-230). Kraków: Wydawnictwo WAM.

Mironowicz, A. (2006). Metropolia kijowska w strukturze patriarchatu konstantynopolitańskiego (988-1685). In: A. Mironowicz, U. Pawluczuk, \& P. Chomik, (eds.). Autokefalie Kościoła prawosławnego w Polsce (pp. 24-46). Białystok: Wydawnictwo Uniwersytetu w Białymstoku.

Mokry, W. (1994). Stosunek państwowych i cerkiewnych władz moskiewskich do ukraińskiej Cerkwi prawosławnej i unickiej w wiekach XVII-XX. In: R. Łużny, 
F. Ziejka, \& A. Kępiński (eds.). Unia brzeska: geneza, dzieje i konsekwencje w kulturze narodów słowiańskich (pp. 83-94). Kraków: Towarzystwo Autorów i Wydawców Prac Naukowych „UNIVERSITAS”.

Mossakowski, W. (2012). Ugruntowanie autokefalii prawosławia w Polsce współczesnej. Studia Iuridica Toruniensia, 11(1), 113-128. DOI: 10.12775/SIT.2012.021.

Olszański, T.A. (2014). Ukraiński Kościół Prawosławny wobec rewolucji i wojny. Komentarze OSW, 151, 1-8. Retrieved from: https://www.osw.waw.pl/sites/default/ files/komentarze_151_0.pdf.

Olszański, T.A. (2018). Historyczne zjednoczenie Kościołów prawosławnych Ukrainy. Komentarze OSW, 289, 1-6. Retrieved from: https://www.osw.waw.pl/sites/default/ files/komentarze_289_0.pdf.

Papierzyńska-Turek, M. (1989). Między tradycją a rzeczywistością. Państwo wobec prawosławia, 1918-1939. Warszawa: Państwowe Wydawnictwo Naukowe.

Paprocki, H. (1999). Przygotowania do Soboru Panprawosławnego. In: Kalendarz Prawosławny 2000 (pp. 203-208). Warszawa: Wydawnictwo Warszawskiej Metropolii Prawosławnej.

Pawluczuk, W. (1998). Ukraina. Polityka i mistyka. Kraków: Wydawnictwo Nomos.

Plokhy, S., \& Sysyn, F. (2003). Religion and Nation in Modern Ukraine. Toronto and Edmonton: Canadian Institute of Ukrainian Studies Press.

Przeciszewski, P. (2018). Autokefalia prawosławia na Ukrainie. Niedziela: Tygodnik Katolicki. Retrieved from: http://www.niedziela.pl/artykul/35202/ page=2\&perpage $=1$.

Przekop, E. (1978). Wschodni model kolegialnego zarządzania w Kościele. Colloquium Salutis. Wrocławskie Studia Teologiczne, 10(1), 199-212.

Radziwinowicz, W. (2018, May 26). Ukraińska Cerkiew odłacza się od Moskwy. Putin przegrywa wojnę o dusze Ukraińców. Retrieved from: http://wyborcza. pl/7,75399,23450351,ukrainska-cerkiew-odlacza-sie-od-moskwy-putin-przegrywawojne.html.

Ramet, S.P. (1984). Religion and Nationalism in Soviet and East European Politics. Durham: Duke University Press.

Roberson, R.G. (1998). Chrześcijańskie Kościoły Wschodnie. Bydgoszcz: Wydawnictwo Homini.

Romanowski, W. (2018). Ukraińska cerkiew chce się uniezależnić od Rosji. Będzie wojna religijna? Polityka. Retrieved from: https://www.polityka.pl/tygodnikpolityka/ swiat/1746874,1,ukrainska-cerkiew-chce-sie-uniezaleznic-od-rosji-bedzie-wojnareligijna.read.

Sokołowski, J. (2013). Autokefaliczne Kościoły Prawosławne. Periodyk Naukowy Akademii Polonijnej, 1(7), 255-272.

Sterlingow, P. (2018, September 7). Nowi egzarchowie na Ukrainie. Retrieved from: www. wiadomosci.cerkiew.pl/news.php?id_n=1911.

Strutyński, M. (2014). Stosunki między państwem a związkami wyznaniowymi w niepodległej Ukrainie (1991-2013). Studia z Prawa Wyznaniowego, 17, 255-273. 
Szeptycki, A. (2011). O jedność słowiańskiego prawosławia. Nowa Europa Wschodnia, $1,64-75$.

Szostkiewicz, A. (2018). Ukraińska cerkiew zrywa z Moskwą. Polityka. Retrieved from: https://www.polityka.pl/tygodnikpolityka/swiat/1766418,1,ukrainska-cerkiewzrywa-z-moskwa.read.

Tatarenko, L. (2017). Instytucje religijne i polityka na Ukrainie: zagadnienie tożsamości w czasach wojny. Rocznik Instytutu Europy Środkowo-Wschodniej, 15(1), 13-41.

Tataryn, M. (2001). Russia and Ukraine: Two Models of Religious Liberty and Two Models for Orthodoxy. Religion, State \& Society, 29(3), 155-172. DOI: $10.1080 / 09637490120107272$.

Tofiluk, J. (2006). Autokefalia w rozumieniu Kościoła prawosławnego. In: A. Mironowicz, U. Pawluczuk, \& P. Chomik (eds.). Autokefalie Kościoła prawosławnego w Polsce (pp. 6-22). Białystok: Wydawnictwo Uniwersytetu w Białymstoku.

Wawrzonek, M. (2014). Religion and Politics in Ukraine: The Orthodox and Greek Catholic Churches as Elements of Ukraine's Political System. Newcastle upon Tyne: Cambridge Scholars Publishing.

Wawrzonek, M. (2016). "Russkiy mir": A Conceptual Model of the "Orthodox Civilization”. In: M. Wawrzonek, N. Bekus, \& M. Korzeniewska-Wiszniewska (eds.). Orthodoxy Versus Post-Communism?: Belarus, Serbia, Ukraine and the Russkiy Mir (pp. 37-70). Newcastle upon Tyne: Cambridge Scholars Publishing.

Wilson, A. (2002). Ukraińcy. Warszawa: Bertelsmann Media.

Vassiliadis, P. (2018). Ukrainian Autocephaly. What Next? The Role of Patriarch Bartholomew. Retrieved from: https://risu.org.ua/en/index/expert_thought/ open_theme/73323.

Znosko, A. (1971). Autokefalia. Próba kanonicznego ujęcia przedmiotu w skrócie. Wiadomości Polskiego Autokefalicznego Kościoła Prawosławnego (pp. 38-51). Warszawa: Warszawska Metropolia Prawosławna.

Znosko, A. (1973). Prawosławne prawo kościelne, cz. 1. Warszawa: Chrześcijańska Akademia Teologiczna.

Zyzykin, M. (1931). Autokefalia i zasady jej zastosowania. Warszawa: Instytut Wydawniczy „Biblioteka Polska”. 